\title{
DETEKSI DINI KETERLAMBATAN PERKEMBANGAN MOTORIK KASAR PADA ANAK
}

Oleh: B. Suhartini

Dosen Jurusan Pendidikan Kesehatan dan Rekreasi FIK UNY

Abstrak

Perkembangan motorik berarti perkembangan pengendalian gerakan jasmaniah melalui kegiatan pusat saraf dan otot yang terkoordinasi. Pengendalian tersebut berasal dari perkembangan refleksi dan kegiatan masa yang ada pada waktu lahir. Kondisi ketidakberdayaan pada anak akan berubah secara cepat, selama empat tahun atau lima tahun pertama kehidupan pascalahir anak dapat mengendalikan gerakan yang kasar. Gerakan-gerakan tersebut melibatkan bagian badan yang luas, seperti tengkurap, duduk, merangkak, berdiri merambat, berjalan, berlari, melompat, dan meloncat. Perkembangan motorik kasar anak dapat diketahui melalui pemantauan yang cermat.

Kemampuan motorik kasar akan berkembang dengan baik apabila ada perhatian orang tua dan latihan yang baik. Kebebasan bergerak yang diberikan pada anak pada masa pertumbuhan akan berpengaruh terhadap pertumbuhan dan perkembangan anak selanjutnya. Secara umum perkembangan motorik dibagi menjadi dua, yakni motorik kasar dan motorik halus. Motorik Kasar merupakan aktivitas motorik yang mencakup keterampilan otot-otot besar, sedangkan motorik halus mencakup keterampilan otot-otot kecil. 
Keterlambatan yang terjadi bisa bersifat fungsional atau ada kerusakan pada susunan pusat saraf,seperti cerebral palsy, perdarahan otak, asfiksia, benturan kepala yang berat, serta adanya kelainan sumsum tulang belakang dan gangguan saraf tepi. Ada beberapa gejala yang merupakan pertanda terjadinya gangguan pada perkembamgam motorik kasar anak, di antaranya terlalu kaku atau lemah, ukuran kepala bayi abnormal, pernah kejang, melakukan gerakan aneh, terlambat bicara, dan proses persalinan tidak mulus.

Kata kunci: deteksi dini, motorik kasar.

Proses tumbuh kembang kemampuan gerak seorang anak disebut perkembangan motorik. Masa lima tahun pertama kehidupan seorang anak adalah masa emas bagi perkembangan motoriknya, karena pada usia tersebut kondisi tubuh masih dalam keadaan lentur dan mudah diarahkan.

Secara umum perkembangan motorik bisa dibagi menjadi dua, yaitu motorik kasar dan motorik halus. Motorik kasar adalah bagian dari aktivitas motorik yang mencakup keterampilan otot-otot besar, dimulai dari tengkurap, duduk, merangkak, berdiri, hingga berjalan. Perkembangan motorik kasar juga meliputi perkembangan sikap tubuh dan gerakan atau lokomasi. Pada usia lima tahun pertama motorik kasar si kecil adalah yang lebih dominan berkembang, keterampilan motorik ini akan berkembang sejalan dengan kematangan koordinasi antara saraf dan otot. Setiap gerakan yang dilakukan anak, sesederhana apa pun sebenarnya mencakup pola interaksi yang kompleks dari berbagai bagian dan sistem dalam tubuh yang dikontrol oleh otak (Graham, 1980: 109).

Bayi harus menunggu selama kurang lebih satu tahun melakukan langkah awal pertamanya. Sebagai makhluk mungil yang tidak berdaya, bayi sangat bergantung pada orang lain. Itulah sebabnya dalam perkembangan motorik kasar bayi membutuhkan kerja sama dari ke dua orang tuanya. Perkembangan motorik anak diawali dengan refleks yang sebagaian di antaranya sudah terjadi pada saat bayi berada dalam kandungan, misalnya

Vol. I, No. 2, Oktober 2005: 177-185. 
refleks mengisap jempol. Refleks adalah gerakan yang terjadi tanpa disadari (Hurlock, 1993: 162) gerakan yang dilakukan anak merupakan gerakan yang belum banyak terkoordinasi, menyeluruh dan tidak produktif. Posisi tubuh dan gerakan bayi baru lahir hingga usia 2 bulan umumnya didominasi oleh refleks primitif, misalnya refleks menggenggam begitu jari tangan disentuh telapak tangan anak akan menggenggam.

Reflek lain yang sudah dikuasai anak sejak lahir adalah ketegangan leher, bila ditidurkan dalam posisi telentang bayi akan memiringkan kepalanya ke satu sisi serta meluruskan lengan dan kakinya pada sisi tersebut. Sementara itu, lengan dan kaki sisi satunya akan sedikit ditekuk. Selain reflek tersebut masih ada refleks yang tidak segera tampak dan harus dirangsang untuk beberapa waktu lamanya yaitu refleks berjalan dan refleks merayap, misalnya apabila anak dipegang pada ketiaknya pada posisi berdiri dalam beberapa saat bayi seakan-akan melakukan gerakan-gerakan berjalan (Graham, 1980: 203). Apabila anak diletakkan dalam posisi tengkurap beberapa saat kemudian anak tersebut akan melakukan gerakan merayap atau berenang. Hal yang perlu diingat adalah jangan memaksa bayi melakukan gerakan sebelum waktunya, karena akan dapat mengganggu tumbuh kembang ototnya. Pada dasarnya semua refleks primitif merupakan persiapan dan latihan yang tidak disadari otot-otot bayi dan hal ini terjadi jauh sebelum bayi tahu cara menggunakan otot-otot tubuhnya secara sadar.

\section{PERKEMBANGNYA MOTORIK KASAR}

Setelah usia 2 bulan, refleks-refleks bayi akan menghilang dengan sendirinya, bersamaan dengan itu anak mulai menggerak-gerakkan tangannya di depan matanya dan mengamatinya dengan saksama. Kegiatan ini penting karena merupakan awal dari pengenalan dirinya dengan dunia luar dan lingkungan sekitarnya. Anak usia 3-4 bulan gerakan yang dilakukan sudah lebih diarahkan oleh kesadarannya, gerakan tersebut dipengaruhi oleh keseimbangan dan koordinasi antara gerakan tubuh. Refleks primitif pun hilang berganti dengan gerakan yang lebih bervariasi. Pada saat anak mulai memasuki tahap perkembangan motorik kasar yang ditandai dengan munculnya gerakan yang lebih terarah.

Deteksi Dini Keterlambatan Perkembangan Motorik Kasar pada Anak (B. Suhartini) 
Perkembangan motorik kasar anak dapat diketahui melalui pemantauan yang cermat, sebagai orang tua perlu mencocokkan keterampilan yang sudah dikuasai anak dengan usianya. Berikut beberapa kemampuan motorik kasar yang umum dikuasai anak sesuai dengan tahap umur dan perkembangannya (Hurlock, 1993: 169).

\section{Kontrol kepala}

Pada awal kehidupan bayi banyak melakukan aktivitas yang berhubungan dengan pengembangan kontrol gerakan. Penguasaan kontrol gerakan bermula dari bagian kepala kemudian turun ke kaki, namun yang pertama kali dikuasai adalah kontrol gerakan leher. Dalam posisi tengkurap biasanya bayi usia satu bulan baru dapat mengangkat kepala selama beberapa saat dan memiringkan ke satu sisi saja. Pada usia dua bulan barulah bayi akan mengankat kepala sekitar 45 derajad dari permukaan (Graham, 1980). Pelajaran mengangkat kepala ini melatih saraf serta otot-otot leher dan perut, usia 6 bulan bayi mahir mengangkat kepala, dada, dan perut atas sambil bertumpu pada telapak tangannya.

Posisi telentang bayi usia 3 bulan biasanya sudah dapat mengangkat kepala, tetapi karena leher belum kuat kepala agak terkulai (head lag). Setelah berusia 5 bulan leher sudah lebih kuat, sehingga kepalanya juga sudah lebih tegak, usia 7 bulan baru anak dapat mengangkat secara spontan.

\section{Kontrol batang tubuh}

Kemampuan bayi untuk mengontrol batang tubuhnya terlihat dari berbagai gerakan yang dilakukan diantaranya adalah sebagai berikut:

\section{a) Berguling}

Pada usia 1-2 bulan biasanya bayi melakukan gerakan berputar dari posisi telentang hingga posisi miring, dimulai dari berputarnya kepala diikuti dengan berputarnya batang tubuh. Usia 4 bulan bayi sudah mahir tengkurap tanpa dibantu siapa pun, usia 5-7 bulan dimotori putaran kepala, bayi akan berguling dari posisi tengkurap ke posisi telentang dan sebaliknya.

MEDelkera Vol. I, No. 2, Oktober 2005: 177-185. 
b) Duduk

Kontrol yang baik pada otot punggung dan bahu akan membuat anak duduk sendiri tanpa bantuan orang lain. Bayi usia 1 bulan apabila didudukkan punggung biasanya akan melengkung, usia 4 bulan punggung sudah tidak melengkung lagi. Sekalipun bayi sudah bisa duduk tubuhnya masih agak sedikit condong ke depan, pada usia 5 bulan biasanya sudah dapat duduk tanpa bantuan.

c) Merangkak

Merangkak merupakan gerakan tubuh berumpu pada tangan dan lutut. Sekitar usia 6-7 bulan umumnya bayi sudah bisa mengangkat badan dan pantat dengan kedua tangan dan kaki sebagai penopang, namun hanya bergerak maju mundur tanpa melangkah maju, di usia 7-10 bulan baru bayi benar-benar mulai merangkak.

d) Berdiri

Kekuatan otot lengan dan bahu anak mulai menarik tubuhnya dalam posisi berdiri. Pelajaran ini biasanya sudah dikuasai anak antara usia 8-10 bulan. Gerakan berdiri memungkinkan anak untuk mengembangkan otot-otot kaki.

e) Berjalan

Salah satu keterampilan motorik yang paling jelas menandai kemandirian anak adalah berjalan. Kini anak bergerak kemana saja tanpa bantuan orang lain, umumnya aktivitas ini pada anak usia 12 bulan.

Ketika otot telah mengembangkan berbagai kekuatan yang ada pada tubuhnya anak akan mencoba menguasai keseimbangan tubuh dengan membuat 1-2 langkah pendek. Pada mulanya tentu ia akan jatuh bangun, karena belum bisa menguasai keseimbangan tubuhnya. Minat untuk belajar berjalan serta makin baiknya perkembangan kekuatan ototnya, pada akhirnya akan membantu si kecil mengayunkan kaki untuk melanngkah dan berjalan dengan tegap.

\section{Keterlambatan Motorik Kasar}

Biasanya sulit membedakan apakah perkembangan motorik kasar anak termasuk normal atau tidak. Proses kematangan setiap anak memang

Deteksi Dini Keterlambatan Perkembangan Motorik Kasar pada Anak (B. Suhartini) 
tidak selalu sama, sehingga laju perkembangan antara anak yang satu dari yang lain sangat berbeda. Itulah sebabnya ada anak yang bisa berjalan ketika usianya mencapai 12 bulan, sementara anak lain baru bisa berjalan pada usia 15 bulan. Sekalipun demikian tidak berarti bayi yang bisa cepat berjalan lebih pandai dari bayi yang relatif lebih lambat berjalan. Setiap anak pada dasarnya memiliki kecepatan perkembangan yang berbeda-beda, sehingga kemungkinan anak yang terlambat berjalan justru lebih cepat dalam perkembangan berbicaranya. Yang lebih penting adalah memantau perkembangan motorik anak terlambat atau sesuai dengan norma perkembangan yang ada, apabila ada keterlambatan perlu diperiksa secara saksama.

Keterlambantan yang terjadi bisa bersifat fungsional yang tidak berbahaya, atau merupakan tanda adanya kerusakan pada susunan saraf, seperti cerebral palsy atau gangguan sistem motorik yang disebabkan oleh kerusakan bagian otak yang mengatur kemampuan gerak otot-otot tubuh, perdarahan otak, asfiksia atau bayi tidak langsung menangis saat lahir, benturan atau trauma kepala yang berat, serta adanya kelainan sumsum tulang belakang dan gangguan saraf tepi atau penyakit saraf tepi atau poliomielitis yang menyebabakan kelumpuhan serta penyakit otot atau distrofia muskulorum

Ada beberapa gejala yang merupakan pertanda terjadinya gangguan pada perkembangan motorik kasar anak, antara:

\section{Terlalu kaku atau lemah}

Misalnya bayi usia 5 bulan masih mengepal telapak tangannya, tubuh agak kaku saat digendong, serta cenderung membanting-banting diri ke belakang. Saat diberdirikan dengan bertopang pada ketiaknya, tungkai kecil terjulur kaku, pada waktu berbaring telentang tanpa melakukan gerakan apa pun, serta kepala tidak bisa diangkat (terkulai) saat digendong, semua menunjukkan motorik kasar anak terlalu kaku atau lemah.

\section{Ukuran bayi abnormal}

Apabila kepala anak terlalu besar kemungkinan menderita bidrosefalus atau menimbunnya cairan dalam otak, sementara apabila

Vol. I, No. 2, Oktober 2005: 177-185. 
kepala terlalu kecil kemungkinan merupakan pertanda tidak maksimalnya perkembangan otak si anak.

\section{Pernah kejang}

Kejang yang terjadi merupakan pertanda adanya kerusakan dalam sistem saraf pusat.

\section{Melakukan gerakan aneh}

Misalnya bayi menunjukkan gerakan seperti berputar-putar sendiri tanpa koordinasi atau tujuan yang jelas.

\section{Terlambat bicara}

Usia bayi menginjak satu tahun misalnya baru bisa mengucap ah.......atau oh......

\section{Proses persalinan tidak mulus}

Misalnya ibu mencoba menggugurkan kandungan, atau proses kelahiran kurang baik, misalnya bayi dipaksa lahir secara alami, sehingga terjadi trauma pada kepala.

Hal-hal yang menghambat perkembangan motorik kasar, seperti kelahiran sulit, terutama apabila disertai trauma di kepala, anak dengan intelegensi rendah, lingkungan artinya orang tua terlalu protektif sehingga menghambat kebebasan anak untuk melatih keterampilan motorik kasarnya, misal anak tidak boleh menggunakan tungkainya karena ada ketakutan orang tua tungkai anak akan menjadi bengkok. Anak sangat berhati-hati merupakan hambatan juga dalam mengembangkan motorik kasar, misalnya pada saat belajar berjalan takut jatuh atau cedera. Sebenarnya anak sudah dapat berjalan sambil dipegang pada satu jarinya, namun apabila pegangan dilepas anak akan mogok berjalan dan langsung duduk atau berdiri di tempat. Kelahiran dini atau prematur bisa menghambat perkembangan motorik kasar anak karena tingkat perkembangan pada saat lahir di bawah bayi normal. Penghambat lain juga dikarenakan cacat fisik misalnya anak mengalami 
kebutaan, juga perbedaan pola asuh yang berkaitan dengan jenis kelamin, anak perempuan tidak diberi kebebasan sebesar kebebasan anak laki-laki.

\section{Fisioterapi}

Sebelum menentukan terapi yang paling tepat untuk mengatasi keterlambatan perkembangan motorik kasar anak, langkah pertama yang harus dilakukan orang tua adalah menelusuri penyebabnya. Apabila penyebabnya adalah lingkungan yaitu misalnya seperti akibat sikap protektif orang tua, sebagai orang tua harus mengubah pola asuh yang diberikan anak, biarkan anak bergerak dengan bebas dan leluasa. Kebebasan bergerak yang diberikan akan memberikan kemandirian gerak pada anak, dengan cara ini anak akan termotivasi untuk belajar menguasai semua tahapan perkembangan secara alami dan benar.

Apabila penyebabnya adalah otot yang tidak berkembang secara optimal, anak kekurangan tenaga untuk beraktivitas, adanya kerusakan susunan saraf pusat, saraf tepi serta kelainan sumsum tulang belakang, anak harus dibawa ke dokter ahli anak terlebih dahulu untuk mengetahui secara pasti kelainan yang diderita anak. Selanjutnya, akan diarahkan untuk melekukan fisioterapi yang sesuai dengan kelainan yang diderita anak.

Di samping kondisi lingkungan dan kesehatan anak, keterlambatan perkembangan motorik kasar anak dapat juga disebabkan kurang bergerak atau rangsangan serta motivasi yang diberikan sangat kurang. Fisioterapi lebih awal akan membantu mengembangkan kemampuan motorik kasar anak agar berkembang lebih optimal.

\section{KESIMPULAN}

Motorik kasar adalah tahapan perkembangan yang harus dilalui oleh anak. Keterlambatan yang dialaminya akan berpengaruh pada kemampuan gerak selanjutnya. Usia lima tahun pertama motorik kasar lebih dominan berkembang, maka pada masa ini anak lebih baik diberi kebebasan bergerak agar perkembangan motorik kasarnya berkembang secara optimal.

Vol. I, No. 2, Oktober 2005: 177-185. 


\section{DAFTAR PUSTAKA}

Faras H. (2004). Motorik Kasar dan Halus. Jakarta: Nakita.

Graham. G. (1980). Children Moving. California: Maifield Publishing.

http:/.www.tempo.co.id/medika/arsip/war-1.htm. (2001).

http:/www.tabloit-nakita.com. (2004).

Maggil, R.A. (1998). Motor Learning. Concepts and Applications. Boston: McGrawHilll International Editions.

Rusli Lutan. (1998). Belajar Keterampilan Motorik Pengantar Teori dan Metode. Jakarta: P2LPTK.

Hurlock. (1993). Perkembangan Anak. Jakarta: Erlangga. 